\title{
Effect of the Real Exchange Rate on the Sustainability of Current Account Deficits in Sub-Saharan African Countries
}

\author{
Moumini Bamogo \\ Department of Economics and Management, Thomas Sankara University, Ouagadougou, Burkina Faso \\ Email address: \\ bamogomoumini88@yahoo.fr \\ To cite this article: \\ Moumini Bamogo. Effect of the Real Exchange Rate on the Sustainability of Current Account Deficits in Sub-Saharan African Countries. \\ Journal of Business and Economic Development. Vol. 5, No. 4, 2020, pp. 224-238. doi: 10.11648/j.jbed.20200504.15
}

Received: October 24, 2020; Accepted: November 10, 2020; Published: November 19, 2020

\begin{abstract}
Sub-Saharan African countries run many current account deficits in the context of the new world economic order, namely globalization. The theoretical literature reveals that the real exchange rate improves the sustainability of the current account deficit, the effect of which may differ according to the type of exchange rate regime. Empirically, the authors are not unanimous on this issue. This paper analyses the effect of the real exchange rate on the sustainability of current account deficits in Sub-Saharan African countries over the period 1980-2016. Using a logit model applied to a panel of 38 countries and estimated using the maximum likelihood method, it appears that the depreciation of the real exchange rate has a positive effect on the sustainability of the current account deficit. This effect depends on the type of exchange regime. Under a floating exchange rate regime, the real exchange rate acts positively on the sustainability of the current account deficit when this rate is less than or equal to 250 . On the other hand, under an intermediate exchange rate regime, the real exchange rate increases the sustainability of the current account deficit when the rate is between 275 and 600. In the case of the fixed exchange rate regime, the real exchange rate has a positive effect on the sustainability of the current account deficit if the rate is greater than or equal to 700. In the light of these results, the paper suggests to policymakers, the use of the real exchange rate to improve the sustainability of current account deficits. These policymakers should use real exchange rates below 250 for countries adopting a floating exchange rate regime, between 275 and 600 for the intermediate exchange rate regime, and greater than 700 for the fixed exchange rate regime.
\end{abstract}

Keywords: Real Exchange Rate, Exchange Rate Regime, Sustainability of Current Account Deficits, Sub-Saharan Africa

\section{Introduction}

The study of the role of the real exchange rate in the sustainability of current account deficits is of particular interest in the literature. Indeed, the persistence of large current account deficits is generally perceived as a cause of financial crisis [1]. This implies difficulties in mobilizing external resources to finance economic activities.

The real exchange rate is the nominal exchange rate deflated by relative prices. It can be bilateral or effective. The bilateral real exchange rate indicates under the same currency, the price of a basket of goods in a given country compared to the price of the same basket in another country. As for the real effective exchange rate, it represents an average of a country's real bilateral exchange rates with its trading partners, weighted by the respective market shares of each partner.
The sustainability of the current deficit is defined as the ability of a country to generate sufficient trade surpluses in the future in order to meet its external commitments [2].

From a theoretical standpoint, the need to implement measures to reduce current account deficits raises two main centuries-old debates. The first contrasts the classical tradition and the keynesian tradition or monetary approach to the balance of payments on the need for such measures. The classical tradition emphasizes the self-regulating capacity of the market, while believing that by virtue of the flexibility of domestic prices, the imbalance adjusts automatically. From this perspective, any measures to improve the sustainability of current account deficits remain unnecessary. The keynesian tradition and the monetary approach to the balance of payments, on the contrary, suggest the implementation of measures to correct imbalances, due to the rigidity of domestic prices. 
The second debate concerns the origin of the imbalances in the balance of payments, and opposes the Keynesians and the authors of the monetary approach to the balance of payments [3-5]. The authors of the monetary approach to the balance of payments consider that current account deficits are explained by an excess supply of money relative to the demand for money. The source of the deficits would be the monetary sector of the economy. Keynesians, on the other hand, believe that the origin of deficits lies in the real sector of the economy. As such, two main approaches are developed in the literature: the absorption approach based on controlling domestic demand, and the elasticity approach based on the exchange rate.

In this article, special emphasis is given to the real exchange real. This is because the literature shows that, in an increasingly globalized environment, economic relations are more sensitive to changes in real exchange rates [6-8]. This, in turn, affects the sustainability of countries' current account balances.

In the particular case of Sub-Saharan African (SSA) countries, they are experiencing persistent current account deficits, which have risen from an average of 1.3 per cent of gross domestic product (GDP) in 1980 to 4 per cent in 2016, an increase of 2.7 percentage points, according to International Monetary Fund (IMF) World Economic Outlook (WEO) data.

The main question is whether variations in real exchange rates improve the sustainability of current account deficits in SSA countries?

Looking at previous empirical studies, very few studies in our view include the difference in the type of exchange rate regime in the analysis [9-13]. However, the floating exchange rate regime is more conducive to the correction of external imbalances than other types of exchange rate regimes [14]. Likewise, very little work integrates geographical affiliation in the analysis of the relationship between the real exchange rate and the current account balance, and the results may vary from one subregion to another. This article takes these different aspects into account.

The main results obtained in this paper show that the real exchange rate has an overall positive effect on the sustainability of the current account deficit in SSA countries. Under a floating exchange rate regime, this positive effect is observed for real exchange rate levels less than or equal to 250. On the other hand, under an intermediate exchange rate regime, the real exchange rate has a positive influence on the sustainability of the current account deficit when it is between 275 and 600 . In the case of the fixed exchange rate regime, higher levels of the real exchange rate, greater than or equal to 700 , are required to achieve a positive effect on the sustainability of the deficit. The results are almost similar to those obtained with the subregions considered.

The rest of the article is organized as follows. The second section revisits the economic literature on the relationship between the real exchange rate and the current account. The third highlights the methodological approach. The fourth describes the data used. The fifth presents and discusses the empirical results. The last section concludes the study and provides implications of economic policy.

\section{Literature Review}

This section highlights the theoretical and empirical underpinnings of the effect of the real exchange rate on current transactions. The theoretical literature is presented first. In a second step, the empirical literature is analysed.

\subsection{Theoretical Literature Review}

The theoretical literature analyses, on the one hand, the role of the real exchange rate in explaining current transactions and, on the other hand, the effect of the exchange rate regime on the current account.

\subsubsection{Relationship Between the Exchange Rate and the Current Account}

The relationship between the exchange rate and the current account is notably explained in the literature by the elasticity approach [3]. According to this approach, when the critical elasticities theorem is verified, the depreciation or devaluation of the exchange rate improves the competitiveness of the economy, and therefore produces the expected beneficial effects. The critical elasticities theorem specifies the extent to which a current account balance is improved by a depreciation of the national currency on the foreign exchange market or by a devaluation of the currency by the monetary authorities [15].

The depreciation or devaluation of the exchange rate essentially produces three effects on the economy: the deterioration of the terms of trade effect, the volume effect and the effect of capital inflows.

The first effect comes from the fact that devaluation changes the price of imports which tends to rise in national currency, while the price of exports in national currency remains constant. In addition, the price of exports tends to decrease in foreign currency, while the price of imports remains unchanged in foreign currency. This situation leads to a deterioration in the terms of trade, which, by definition, correspond to the ratio between the export price index and the import price index.

The volume effect reflects the increase in the volume of exports resulting from lower export prices and the decrease in the volume of imports resulting from higher import prices. The increase in the volume of exports and the reduction in the volume of imports contribute to an improvement in the current account position.

The effect of capital inflows is the result of the action of speculators who send capital from foreign currency markets back to the domestic country's currency market after the exchange rate has been changed to take advantage of the devaluation premium. The latter effect has a positive influence on the current balance of payments.

Unlike the elasticity approach, the J-curve theory shows that when the criterion of critical elasticities is satisfied, the improvement of the current account position through 
depreciation or devaluation of the exchange rate is not immediate [16]. Indeed, this devaluation leads to a deterioration of the current balance in the short term, followed by an improvement in the medium term. This is because consumers in the countries concerned do not react to changes in the relative prices of domestic and foreign goods in the short term. The evolution of the current balance, characterized by a deterioration followed by an improvement is referred to as the $\mathrm{J}$ curve.

\subsubsection{Relationship Between the Exchange Rate Regime and the Current Account}

This subsection aims to show how the exchange rate regime affects the relationship between the real exchange rate and the current balance. In this framework, the floating exchange rate regime is conducive to reducing current account imbalances [14]. Indeed, under a flexible exchange rate regime, the nominal exchange rate adjusts automatically and continuously through the free play of the money market, thus eliminating any possibility of accumulation of current imbalances. Under this regime, countries with current account deficits see their exchange rates depreciate, thus improving the competitiveness of the economy.

In contrast, for some authors, the exchange rate regime effect depends on the degree of mobility of production factors $[17,18]$. In a context of high factor mobility, moving production factors from one country to another adjusts relative prices, thereby facilitating the return to current account equilibrium. Under these conditions, the flexible exchange rate regime is not essential for reducing imbalances.

For other authors, the fixed exchange rate regimes are an effective means of reducing current imbalances in an environment of high economic openness [19]. Indeed, exchange rate fixity ensures price stability in a situation of high trade openness, and therefore improves current transactions.

It is also pointed out in the literature that a poorly diversified economy has an interest in adopting a flexible exchange rate regime to improve its balance of payments [20]. This floating regime has the advantage, unlike the fixed exchange rate regime, of cushioning external shocks through automatic variations in the nominal exchange rate.

\subsection{Empirical Literature Review}

Empirical studies of the effect of the real exchange rate on the current account are first reviewed. Those relating to the effect of the exchange rate regime on the current account are analysed in a second step.

\subsubsection{Real Exchange Rate and Current Balance}

Many authors find in their empirical work a positive influence of the depreciation of the real exchange rate on the current account. For example, the results of the estimation of an error correction model (ECM) over the period 1962-2005, show that an increase in the real exchange rate of 1 per cent, leads to an increase in Argentina's trade balance of 0.61 per cent [9].
Likewise, another analysis looks at the determinants of Turkey's current account balance with Germany, using the same methodology over the period 2002-2014 [11]. The results indicate that the depreciation of the real exchange rate has a positive effect on the current account for 54 of the 96 product groups considered.

Along the same lines, two authors use both a linear and a non-linear approach of the AutoRegressive Distributed Lag (ARDL) model to study the effect of the real exchange rate on the bilateral trade balance between the United States and thirteen of its partners over the period 1993-2016 [13]. The results reveal a favourable effect of the depreciation of the real exchange rate in the framework of bilateral trade between the United States and six partners using the linear approach, and between the United States and ten partners with the non-linear approach.

In contrast to previous studies, others show that the real exchange rate depreciation negatively affects current transactions. This is the case for the analysis of the effect of the real exchange rate on Gabon's trade balance over the period 1980-2005 using an ECM [10]. The results obtained indicate that a 1 per cent rise in the real exchange rate leads to a 2.37 per cent deterioration in the trade balance. Contrary to economic theory, a depreciation of the real exchange rate does not translate into an improvement in Gabon's current account balance. The authors explain this situation by the fact that the Gabonese economy is poorly diversified, with imports consisting of about 94 per cent agro-industrial products and exports dominated by crude oil with no added value.

A study through an ECM over the period 1970-2012, shows that the depreciation of the real exchange rate leads to a deterioration of Nigeria's current account balance [12]. An increase in the real exchange rate of 10 per cent is accompanied by a decline in the trade balance of 38 per cent. The authors explain this paradox by the flexible exchange rate regime adopted since 1986, which has failed to successfully transform production and consumption patterns.

Contrary to the studies presented above, an examination of the relationship between the real exchange rate and Malaysia's trade balance over the period 1974-2003, through an ARDL model and an autoregressive vector model (VAR), concludes that there is no long-term relationship between the real exchange rate and the trade balance [21]. This result may be due to the insufficient period of the study limited to only 30 years.

\subsubsection{Exchange Regime and Balance of Current Payments}

The empirical literature distinguishes two categories of studies on this point. The first category is made up of studies that highlight the effectiveness of the flexible exchange rate regime compared to the fixed exchange rate regime in correcting current imbalances. A study based on a fixedeffects model applied to 11 Central and Eastern European countries over the period 1994-2007, and estimated by generalized least squares (GLS), indicates that the increase in the degree of exchange rate volatility accelerates the 
adjustment of the current account [22].

Another study also highlights the effectiveness of the flexible exchange rate regime using a consistent stock-flow model applied to economic relations between China, the United States and Europe over the period 1990-2009 [23]. In the case of a fixed yuan-dollar parity, the US current account deficit falls from 9 per cent of GDP in 1990 to 4.9 per cent in 2009, a decline of 4.1 percentage points. On the other hand, in the case of the floating yuan-dollar parity, the deficit falls from 6.7 per cent in 1990 to 0.2 per cent of GDP in 2009, a reduction of 6.5 points.

Analysis of the situation of 181 countries over the period 1980-2011 shows that the probability of a large current account deficit in the current period remaining in the future period is 76 per cent for fixed exchange rate regimes, compared with 50 per cent for flexible exchange rate regimes [24].

In contrast, the second category refers to studies that fail to obtain empirical evidence of the acceleration of the pace of current account adjustment under a flexible exchange rate regime. In this framework, the real exchange rate is more effective in absorbing current account deficits between euro area countries than between euro area and non-euro area countries over the period 1995-2009 [25]. The increase in the real exchange rate of 1 point leads to an increase in the current account balance of 0.12 point in the euro area and 0.08 point with countries outside the euro area whose exchange rate is floating.

Two economists examine the determinants of the degree of persistence of current account deficits in 70 countries over the period 1970-2010, using an autoregressive model estimated by ordinary least square (OLS) [26]. The results show that the exchange rate regime does not affect the persistence of the current account deficit.

Similarly, two others also indicate the absence of relationship between the floating exchange rate regime and the rate of current account deficit reversal, using data for 170 countries around the world between 1971 and 2005 [27].

\section{Methodological Approach}

The methodological approach covers the specification of the empirical model, the definition of variables and the estimation methods used.

\subsection{Specification of the Empirical Model}

The empirical analysis is based on an earlier methodology [28]. This methodology best fits the expectations for testing the hypothesis formulated in this paper, namely, a depreciation of the real exchange rate increases the sustainability of the current account deficit in SSA. This methodology uses a panel logit model to analyse the effect of macroeconomic variables on the balance of payments crisis as measured by the current deficit.

The theoretical model is as follows:

$$
\operatorname{logit}\left(\mathrm{p}_{\mathrm{it}}\right)=\ln \left(\frac{\mathrm{p}_{\mathrm{it}}}{1-\mathrm{p}_{\mathrm{it}}}\right)=\beta_{\mathrm{it}} \mathrm{X}_{\mathrm{it}}
$$

With $p_{i t}$ the probability that country $i$ experiences a balance of payments crisis in year $t$, that is, when the current account is less than zero.

$\mathrm{X}_{\mathrm{it}}$ is a set of explanatory variables of the current account such as real GDP, the consumer price index, the growth rate of exports, the growth rate of imports, public expenditure and the external opening rate.

Based on the theoretical model, the linear logit model explaining the sustainability of the current account deficit is formulated as follows:

$$
\operatorname{logit}\left(p_{i t}\right)=\ln \left(\frac{p_{i t}}{1-p_{i t}}\right)=\beta_{0}+\beta_{i t} X_{i t}+\alpha_{i}+\varepsilon_{i t}
$$

Where $\beta_{0}$ denotes the constant, $\beta_{i}$ he parameters to be estimated, $\alpha_{i}$ the specific effects which may be fixed or random and $\varepsilon_{i t}$ the term random disturbances.

The vector $\mathrm{X}_{\text {it }}$ is a set of factors that may influence the sustainability of the current account deficit of country $i$ at date t. On the basis of the literature and the objective pursued in the study, the explanatory variables retained are: the real exchange rate, the exchange rate regime, domestic absorption, money supply, exports, imports, foreign direct investment, real income, external debt and the budget balance.

The variable $p_{i t}$ in equation 2 indicates the probability that the current account deficit is sustainable. In this paper, this variable is constructed around the theoretical sustainability threshold of -5 per cent of GDP. This choice is essentially motivated by the literature. Indeed, it appears from the literature that a current account deficit reaching the 5 per cent of GDP threshold is excessive, and tends to be unsustainable $[29,30]$. Thus, the sustainability variable takes the value 1 if the current account deficit is sustainable, that is to say when the current balance is greater than or equal to -5 per cent of GDP, and the value 0 otherwise. Formally, it is presented as follows:

$$
\text { Sout }_{\text {it }}=\left\{\begin{array}{l}
1 \text { si CA } \\
\text { it } \geq-0,05 \\
0 \text { si CA } \mathrm{it}_{\mathrm{it}}<-0,05
\end{array}\right.
$$

The variable $\mathrm{CA}_{\mathrm{it}}$ represents the current account of country $\mathrm{i}$ in year $\mathrm{t}$.

Applying the exponential function to model 2 and taking into account the explanatory variables, the empirical model describing the sustainability of the current account deficit is as follows:

$$
\mathrm{p}_{\mathrm{it}}=\frac{1}{1+\mathrm{e}^{-\left(\beta_{0}+\beta_{\mathrm{i}} \mathrm{x}_{\mathrm{it}}+\alpha_{\mathrm{i}}\right)}}
$$

Where $X_{i t}$ groups together the real exchange rate $\left(\mathrm{TCR}_{\mathrm{it}}\right)$, the exchange rate regime $\left(\right.$ Regime $\left._{i t}\right)$, the interaction between the real exchange rate and the exchange rate regime $\left(\mathrm{TCR}_{\mathrm{it}} *\right.$ Regime $\left._{i t}\right)$, the money supply $\left(\mathrm{MS}_{\mathrm{it}}\right)$, real domestic income $\left(\mathrm{GDP}_{\mathrm{it}}\right)$, domestic absorption $\left(\mathrm{ABSORP}_{\mathrm{it}}\right)$, exports $\left(\mathrm{EXP}_{\mathrm{it}}\right)$, imports $\left(\mathrm{IMP}_{\mathrm{it}}\right)$, foreign direct investment $\left(\mathrm{FDI}_{\mathrm{it}}\right)$, external debt $\left(\mathrm{ED}_{\mathrm{it}}\right)$ and budget balance $\left(\mathrm{BB}_{\mathrm{it}}\right)$.

The interaction variable between the real exchange rate 
and the exchange rate regime captures the effect of the real exchange rate on the sustainability of the current account deficit according to the type of exchange rate regime.

\subsection{Definition of Variables}

The real exchange rate variable is measured by the real effective exchange rate. This choice is justified by the fact that it reflects the competitiveness of the economy in relation to all of its trading partners. In addition, this indicator is used in previous work $[9,21]$.

Three dummy variables are used to capture the different types of exchange rate regime, namely the fixed, intermediate and flexible exchange rate regimes. These variables are: Regime 1 which takes the value 1 if the regime is fixed and 0 otherwise, Regime 2 which takes the value 1 if the regime is intermediate and 0 otherwise, and Regime 3 which takes the value 1 if the regime is floating and 0 otherwise. The expected effect of each of these variables is positive.

The money supply is approximated by the ratio of domestic credit to the private sector to nominal GDP. According to the monetary approach to the balance of payments, an excess supply of money relative to the demand for money favours deficits [5]. Consequently, a negative sign is expected for the coefficient associated with the money supply variable.

Real domestic income is captured by real domestic GDP per capita. An increase in real domestic income per capita translates into an improvement in the current account through an increase in domestic production that absorbs part of imports. Thus, the expected effect of this variable is positive.

Domestic absorption is measured by domestic demand which is the sum of consumption expenditure, investment expenditure and government expenditure as a percentage of GDP. According to the theory of absorption, too much domestic demand favours imports [4]. Thus, the expected sign of the parameter associated with this variable is negative.

The export and import variables are measured by exports and imports of goods and services as a percentage of GDP. Exports increase the sustainability of the current account deficit, while imports decrease this sustainability [2]. In this regard, a positive sign is expected from the coefficient associated with the export variable, while a negative sign is expected from the parameter associated with the import variable.

The foreign direct investment variable is captured by foreign direct investment flows as a percentage of GDP. FDI generally results in an increase in imports in the short term, while its positive effect on exports is small and not immediate [31]. However, in the medium and long term, FDI may lead to an improvement in the sustainability of the current account deficit. Consequently, the expected sign of the coefficient associated with the FDI variable is ambiguous.

External debt is taken as a percentage of GDP. It constitutes a means of financing the current deficit. At the same time, the interest payments associated with it can negatively affect the current account. As a result, the effect of external debt on the sustainability of the current account deficit is ambiguous.

The budget balance is approximated by the ratio of the budget balance to nominal GDP. The debate on the relationship between the budget balance and the current account is not resolved in the literature on twin deficits. Indeed, according to the Mundell-Fleming model and the keynesian absorption approach, an increase in the budget deficit leads to an increase in the current account deficit. On the other hand, the ricardian equivalence theory states that an increase in the budget deficit has no effect on the current account in a context of high public debt. Therefore, the expected sign of the parameter associated with the variable remains ambiguous.

Table 1 below summarizes for each variable the abbreviation and the definition used.

Table 1. Definition of Variables.

\begin{tabular}{|c|c|c|}
\hline Variables & Abbreviation & Definition \\
\hline \multicolumn{3}{|l|}{ Dependante Variable } \\
\hline $\begin{array}{l}\text { Current Account } \\
\text { Sustainability }\end{array}$ & CAS & $\begin{array}{l}\text { Value } 1 \text { if the current balance } \\
\geq-0,05 \text { and } 0 \text { otherwise }\end{array}$ \\
\hline Explanatory Variables & & \\
\hline Real Exchange Rate & TCR & Real Effective Exchange Rate \\
\hline $\begin{array}{l}\text { Fixed Exchange Rate } \\
\text { Regime }\end{array}$ & Regime1 & $\begin{array}{l}\text { Vale } 1 \text { if the exchange regime is } \\
\text { fixed et } 0 \text { otherwise }\end{array}$ \\
\hline $\begin{array}{l}\text { Intermediate Exchange } \\
\text { Rate Regime }\end{array}$ & Regime2 & $\begin{array}{l}\text { Value } 1 \text { if the exchange rate is } \\
\text { intermediate and } 0 \text { otherwise }\end{array}$ \\
\hline $\begin{array}{l}\text { Floating Exchange } \\
\text { Rate Regime }\end{array}$ & Regime3 & $\begin{array}{l}\text { Value } 1 \text { if if the exchange rate is } \\
\text { floating and } 0 \text { otherwise }\end{array}$ \\
\hline Money Supply & MS & Private domestic credit to GDP \\
\hline estic Income & GDP & Real GDP per Capita \\
\hline ic Absorption & ABSORP & Domestic demand as $\%$ of GDP \\
\hline & EXP & Exports \% of GDP \\
\hline Imports & IMP & Imports $\%$ of GDP \\
\hline $\begin{array}{l}\text { Foreign Direct } \\
\text { Investment }\end{array}$ & FDI & $\begin{array}{l}\text { Net foreign direct investment } \\
\text { flows as } \% \text { of GDP }\end{array}$ \\
\hline External Debt & ED & External Debt as \% du PIB \\
\hline Budget Balance & BB & $\begin{array}{l}\text { Ratio of fiscal balance to nomina } \\
\text { GDP }\end{array}$ \\
\hline
\end{tabular}

Source: Author.

\subsection{Estimation Methods}

The estimation of the empirical model is made using the maximum likelihood method. The marginal effect of each variable is obtained by deriving or differentiating the dependent variable from the explanatory variable concerned, with the exception of the interaction term. Indeed, the interaction term effect in the case of a non-linear model such as the logit or probit model, cannot be determined by simply examining the sign, magnitude and statistical significance of the coefficient associated with the interaction term [32, 33]. This effect is obtained through the derivative or partial difference of the dependent variable with respect to each of the variables that make up the interaction.

To illustrate the effect of the interaction term in the logit model, the following distribution function is considered:

$$
\mathrm{F}(\mathrm{u})=\frac{1}{1+\mathrm{e}^{-\left(\beta_{1} \mathrm{x}_{1}+\beta_{2} \mathrm{x}_{2}+\beta_{12} \mathrm{x}_{1} \mathrm{x}_{2}+\mathrm{X} \beta\right)}}
$$

Where $\mathrm{F}(\mathrm{u})$ is a density function, $\mathrm{X}$ a set of control variables, $\mathrm{x}_{1}$ and $\mathrm{x}_{2}$ are explanatory variables forming the 
interaction.

of the interaction term is:

If $x_{1}$ and $x_{2}$ are continuous variables, the marginal effect

$$
\frac{\partial^{2} \mathrm{~F}(\mathrm{u})}{\partial \mathrm{x}_{1} \partial \mathrm{x}_{2}}=\beta_{12}[\mathrm{~F}(\mathrm{u})(1-\mathrm{F}(\mathrm{u}))]+\left(\beta_{1}+\beta_{12} \mathrm{x}_{2}\right)\left(\beta_{2}+\beta_{12} \mathrm{x}_{1}\right)[\mathrm{F}(\mathrm{u})(1-\mathrm{F}(\mathrm{u}))(1-2 \mathrm{~F}(\mathrm{u}))]
$$

When $x_{1}$ and $x_{2}$ are dummy variables, the marginal effect of the interaction term becomes:

$$
\frac{\Delta^{2} \mathrm{~F}(\mathrm{u})}{\Delta \mathrm{x}_{1} \Delta \mathrm{x}_{2}}=\frac{1}{1+\mathrm{e}^{-\left(\beta_{1}+\beta_{2}+\beta_{12}+\mathrm{X} \beta\right)}}-\frac{1}{1+\mathrm{e}^{-\left(\beta_{1}+\mathrm{X} \beta\right)}}-\frac{1}{1+\mathrm{e}^{-\left(\beta_{2}+\mathrm{X} \beta\right)}}+\frac{1}{1+\mathrm{e}^{-\mathrm{X} \beta}}
$$

If $x_{1}$ is a continuous variable and $x_{2}$ a dummy variable, the marginal effect of the interaction term takes the following form:

$$
\frac{\Delta \frac{\partial \mathrm{F}(\mathrm{u})}{\partial \mathrm{x}_{1}}}{\Delta \mathrm{x}_{2}}=\left(\beta_{1}+\beta_{12}\right)\left[\mathrm{F}\left(\left(\beta_{1}+\beta_{12}\right) \mathrm{x}_{1}+\beta_{2}+\mathrm{X} \beta\right)\left(1-\mathrm{F}\left(\left(\beta_{1}+\beta_{12}\right) \mathrm{x}_{1}+\beta_{2}+\mathrm{X} \beta\right)\right)\right]-\beta_{1}\left[\mathrm{~F}\left(\beta_{1} \mathrm{x}_{1}+\mathrm{X} \beta\right)\left(1-\mathrm{F}\left(\beta_{1} \mathrm{x}_{1}+\mathrm{X} \beta\right)\right)\right]
$$

It is the latter case that is considered in this paper insofar as the real exchange rate is a continuous variable and the exchange rate regime is a dummy variable.

The solution to take into account the effect of the interaction term in a non-linear model case is to make a graphical representation of the effect of the explanatory variable under consideration, as a function of another variable according to different observations of the explanatory variable [33]. This method is used to determine the marginal effect of the interaction term in the context of this article.

\section{Data}

The paper uses panel data from 38 SSA countries over the period 1980-2016. Eritrea, Liberia, Mauritania, Sao Tome and Principe, Sierra Leone, Zimbabwe, Mauritius, Sudan and South Sudan, are excluded, due to the high number of missing observations over the analysis period.

In addition to SSA, four of its main communities, namely the Economic Community of West African States (ECOWAS), the Economic Community of Central African States (ECCAS), the East African Community (EAC) and the Southern African Development Community (SADC), are also analysed.

Data on exchange rate regimes come from the Ilzetzki, Reinhart and Rogoff's database [34]. This database distinguishes 15 types of exchange rate regime which are classified from pure peg to pure floating. Table 2 below shows

\begin{tabular}{|c|c|c|}
\hline $\mathbf{N}^{\circ}$ & Exchange Regime & Countries or Areas \\
\hline 1 & No separate legal tender or currency union & ECCAS, WAEMU, Zimbabwe \\
\hline 2 & Pre announced peg or currency board arrangement & Cabo Verde, Comoros, Eritrea, Lesotho, Namibia and Swaziland \\
\hline 3 & Pre announced horizontal band that is narrower than or equal to $+/-2 \%$ & \\
\hline 4 & De facto peg & \\
\hline 5 & $\begin{array}{l}\text { Pre announced crawling peg; de facto moving band narrower than or } \\
\text { equal to }+/-1 \%\end{array}$ & \\
\hline 6 & $\begin{array}{l}\text { Pre announced crawling band that is narrower than or equal to }+/-2 \% \\
\text { or de facto horizontal band that is narrower than or equal to }+/-2 \%\end{array}$ & \\
\hline 7 & De facto crawling peg & Burundi, Ethiopia, Guinea, Democratic Republic of Congo and Rwanda \\
\hline 8 & De facto crawling band that is narrower than or equal to $+/-2 \%$ & Gambia, Kenya, Liberia, Mauritius, Mauritania, Soudan and Tanzania \\
\hline 9 & Pre announced crawling band that is wider than or equal to $+/-2 \%$ & \\
\hline 10 & De facto crawling band that is narrower than or equal to $+/-5 \%$ & Botswana, Ghana, Uganda, Sao Tome and Principe, Seychelles and Sierra Leone \\
\hline 11 & Moving band that is narrower than or equal to $+/-2 \%$ & \\
\hline 12 & De facto moving band $+/-5 \% /$ Managed floating & South Africa and Madagascar \\
\hline 13 & Freely floating & \\
\hline 14 & Freely falling & Angola, Malawi, Mozambique, Nigeria and Zambia \\
\hline 15 & Dual market in which parallel market data is missing & \\
\hline
\end{tabular}
the types of exchange rate regimes of SSA countries in 2016.

Table 2. Exchange Rate Regimes of SSA Countries in 2016.

Source: Author based on Ilzetzki, Reinhart and Rogoff's database.

The 15 types of exchange rate regime can be grouped into three broad categories of exchange rate regimes: fixed, intermediate and floating [27].

The category of fixed exchange rate regimes includes: currency union, currency board arrangement, pre announced horizontal band that is narrower than or equal to $+/-2 \%$ and de facto peg.

The category of intermediate exchange rate regimes is composed of the pre announced crawling peg, the pre announced crawling band that is narrower than or equal to $+/$ -
$2 \%$, the de facto crawling peg, the de facto crawling band that is narrower than or equal to $+/-2 \%$, the pre announced crawling band that is wider than or equal to $+/-2 \%$, the de facto crawling band that is narrower than or equal to $+/-5 \%$ and the moving band that is narrower than or equal to $+/-2 \%$.

The category of floating exchange regimes includes the managed floating and the freely floating. For the purposes of this study, the freely falling and the dual market are not included in the category of flexible exchange rate regimes. Indeed, the freely falling and the dual market are 
dysfunctional regimes characterized by very high inflation rates that can exceed 40 per cent per year [34].
Data sources for the other variables are shown in Table 3 below.

Table 3. Data Sources.

\begin{tabular}{lll}
\hline Variable & Abbreviation & Data Sources \\
\hline Current Account Sustainability & CAS & IMF World Economic Outlook \\
Real Exchange Rate & TCR & IMF International Financial Statistics \\
Fixed Exchange Rate Regime & Regime1 & Ilzetzki, Reinhart and Rogoff's database \\
Intermediate Exchange Rate Regime & Regime2 & Ilzetzki, Reinhart and Rogoff's database \\
Floating Exchange Rate Regime & Regime3 & Ilzetzki, Reinhart and Rogoff's database \\
Money Supply & MS & World Bank World Development Indicators \\
Real Domestic Income & GDP & World Bank World Development Indicators \\
Domestic Absorption & ABSORP & World Bank World Development Indicators \\
Exports & EXP & World Bank World Development Indicators \\
Imports & IMP & World Bank World Development Indicators \\
Foreign Direct Investment & FDI & World Bank World Development Indicators \\
External Debt & ED & World Bank World Development Indicators \\
Budget Balance & BB & IMF World Economic Outlook \\
\hline
\end{tabular}

Source: Author

\section{Empirical Analysis}

In order to improve the quality of the results, it is necessary to carry out preliminary tests before estimating the empirical model. Therefore, this section, before presenting and discussing the results, first discusses the Hausman test, then the heteroskedasticity test and finally the prediction test.

\subsection{Hausman Test}

The Hausman test is used to discriminate between the fixed-effect and random-effect models [35]. The results for SSA as a whole, ECCAS and SADC, show that the Chi-2 statistics are negative (see table 5). It is more appropriate in this case to take into account the random effects in the estimation of the model [36].

For ECOWAS and EAC, the p-value associated with the Chi-2 statistic is respectively $99.09 \%$ and $72.51 \%$, therefore above the $5 \%$ threshold. This situation also makes it possible to choose the logit model with random effects.

\subsection{Heteroscedasticity Test}

The White test is used to check whether the errors are heteroscedastic, due to the non-linear nature of the empirical model. This test takes into account the non-linearity [37]. The results obtained from the test indicate that the probability associated with the Fisher statistic is equal to 0.0000 for SSA as a whole, ECOWAS, ECCAS, EAC and SADC (see table 6). The hypothesis of the presence of heteroskedasticity cannot therefore be rejected. In fact, the robust option is taken into account in the model estimates in order to correct the problem revealed by the existence of heteroscedascity.

\subsection{Prediction Test}

The prediction test aims to assess the explanatory power of the specified empirical model. It appears that for SSA countries with sustainable current account deficits, 732 cases out of 909 were well predicted and for countries with unsustainable deficits, 101 cases out of 133 were well predicted (see table 7). The prediction rate, defined as the ratio between the number of well predicted cases and the total number of cases, is therefore $79.94 \%$. This rate is $78.87 \%, 81.85 \%, 89.78 \%$ and $82.14 \%$ for ECOWAS, ECCAS, EAC and SADC respectively. In sum, the specified model has overall a great predictive power.

\subsection{Empirical Model Estimation Results}

The empirical model is first estimated without taking into account the exchange rate regime. The results are shown in Table 4 below.

Table 4. Estimation Results Without Exchange Rate Regime.

\begin{tabular}{|c|c|c|c|c|c|}
\hline \multirow{3}{*}{ Explanatory variables } & \multicolumn{5}{|c|}{ Dependante Variable: Current Account Sustainability } \\
\hline & (1) & (2) & (3) & (4) & $(5)$ \\
\hline & SSA & ECOWAS & ECCAS & EAC & SADC \\
\hline Real Exchange Rate & $\begin{array}{l}0,00076^{* *} \\
(0,048)\end{array}$ & $\begin{array}{l}0,00074 \\
(0,223)\end{array}$ & $\begin{array}{l}0,00004 \\
(0,947)\end{array}$ & $\begin{array}{l}-0,00008 \\
(0,924)\end{array}$ & $\begin{array}{l}0,00135^{* *} \\
(0,011)\end{array}$ \\
\hline Money Supply & $\begin{array}{l}-0,00796^{* *} \\
(0,045)\end{array}$ & $\begin{array}{l}-0,01252^{*} \\
(0,069)\end{array}$ & $\begin{array}{l}-0,01262 \\
(0,105)\end{array}$ & $\begin{array}{l}-0,00802 \\
(0,569)\end{array}$ & $\begin{array}{l}-0,00456 \\
(0,310)\end{array}$ \\
\hline Real Domestic Income & $\begin{array}{l}-0,00002^{* *} \\
(0,025)\end{array}$ & $\begin{array}{l}0,00002 \\
(0,858)\end{array}$ & $\begin{array}{l}-0,00001^{* *} \\
(0,043)\end{array}$ & $\begin{array}{l}0,00005 \\
(0,898)\end{array}$ & $\begin{array}{l}0,00002 \\
(0,525)\end{array}$ \\
\hline Domestic Absorption & $\begin{array}{l}-0,01208^{* * *} \\
(0,001)\end{array}$ & $\begin{array}{l}-0,02392^{* * *} \\
(0,000)\end{array}$ & $\begin{array}{l}-0,00834^{*} \\
(0,050)\end{array}$ & $\begin{array}{l}-0,00730 \\
(0,656)\end{array}$ & $\begin{array}{l}-0,00887^{*} \\
(0,054)\end{array}$ \\
\hline Exports & $\begin{array}{l}0,00334^{*} \\
(0,055)\end{array}$ & $\begin{array}{l}0,00997 \\
(0,188)\end{array}$ & $\begin{array}{l}-0,00144 \\
(0,489)\end{array}$ & $\begin{array}{l}-0,00332 \\
(0,895)\end{array}$ & $\begin{array}{l}0,00499 \\
(0,284)\end{array}$ \\
\hline Imports & $-0,00034$ & $-0,00527$ & 0,00046 & $-0,00970$ & $-0,00594$ \\
\hline
\end{tabular}




\begin{tabular}{llllll}
\hline \multirow{3}{*}{ Explanatory variables } & \multicolumn{5}{l}{ Dependante Variable: Current Account Sustainability } \\
\cline { 2 - 6 } & $\mathbf{( 1 )}$ & $\mathbf{( 2 )}$ & $\mathbf{( 3 )}$ & $\mathbf{( 4 )}$ & $\mathbf{( 5 )}$ \\
\cline { 2 - 6 } & SSA & ECOWAS & ECCAS & EAC & SADC \\
\hline \multirow{3}{*}{ Foreign Direct Investment } & $(0,750)$ & $(0,199)$ & $(0,623)$ & $(0,702)$ & $(0,407)$ \\
& $-0,01871^{* * * *}$ & $-0,00988$ & $-0,02230^{* * *}$ & $-0,03192^{* *}$ & $-0,01088^{*}$ \\
External Debt & $(0,000)$ & $(0,294)$ & $(0,002)$ & $(0,047)$ & $(0,060)$ \\
& $-0,00011$ & 0,00026 & $-0,00058$ & 0,00018 & 0,00005 \\
Budget Balance & $(0,764)$ & $(0,589)$ & $(0,623)$ & $(0,907)$ & $(0,939)$ \\
& $-0,00120^{*}$ & 0,01044 & $-0,00078^{* *}$ & $-0,00654$ & 0,00760 \\
Constant & $(0,088)$ & $(0,115)$ & $(0,032)$ & $(0,648)$ & $(0,157)$ \\
& $10,52^{* * *}$ & $19,66^{* * *}$ & $9,23^{* * *}$ & $17,78^{* * *}$ & $15,41^{* * *}$ \\
Number of observations & $(0,000)$ & $(0,000)$ & $(0,000)$ & $(0,000)$ & $(0,000)$ \\
Chi-2 Statistic & 1406 & 481 & 333 & 185 & 481 \\
P-value & 77,56 & 134,59 & 269,97 & 92,57 & 106,03 \\
& 0,0000 & 0,0000 & 0,0000 & 0,000 & 0,0000 \\
\hline
\end{tabular}

Source: Author.

Note: $* * *, * *$ and $*$ respectively denote the significance of the coefficient associated with the explanatory variable at $1 \%, 5 \%$ and $10 \%$. The numbers in bold represent marginal effects and those in parentheses represent p-values.

The probabilities associated with the Chi-2 statistic are all less than 5\%. This implies that the specified model is globally significant in explaining the sustainability of the current account deficit of SSA countries.

The results obtained show that the real exchange rate has a positive effect on the probability of obtaining sustainable current account deficits in SSA (column 1 of Table 4). An increase in the real exchange rate by 1 point increases the probability of a sustainable current account deficit by 0.00076 point. This result is supported by that found for the case of the United States [13].

The result remains almost the same when the estimate is for SADC. In this case, a depreciation of the real exchange rate by 1 point increases the probability by 0.00135 points. However, the parameter associated with the real exchange rate no longer appears significant for ECOWAS, ECCAS and EAC. This insignificance may be due to the fact that the variation in the real exchange rate is not sufficient to generate trade surpluses to increase sustainability.

The coefficients associated with the control variables such as money supply, domestic absorption, FDI, external debt and budget balance have almost all the expected signs. On the other hand, real domestic income negatively influences the sustainability of the current account deficit in SSA countries, contrary to expectations. This result is probably explained by the fact that an increase in domestic income, instead of promoting domestic production, contributes to increasing imports or investments by national economic agents abroad.

In a second step, the empirical model is estimated taking into account the exchange rate regime and its interaction with the real exchange rate. This gives the possibility to analyse the effect of the real exchange rate according to the type of exchange rate regime.

Figure 1 below presents the results of the effect of the real exchange rate on the sustainability of the current account deficit for SSA countries under a fixed exchange rate regime.

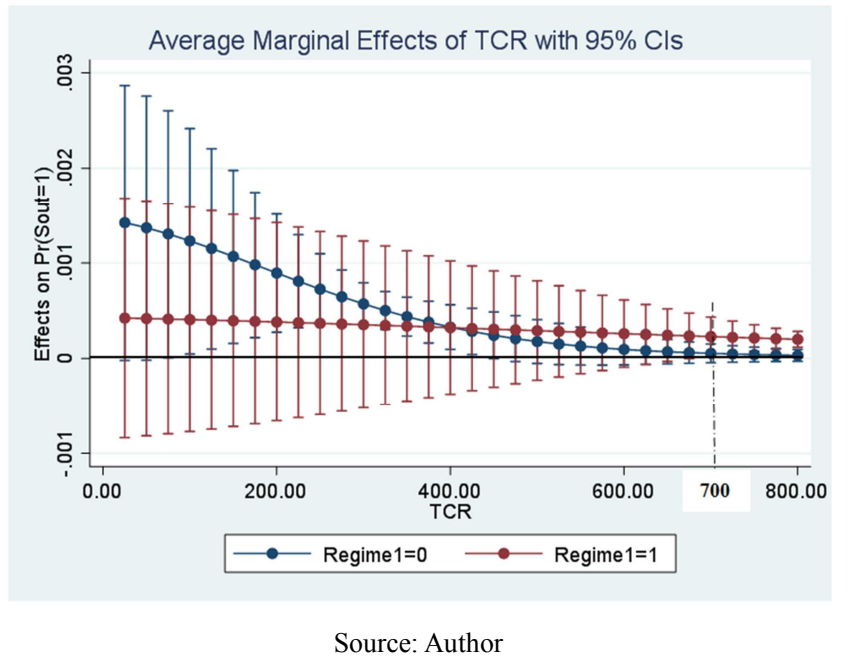

Figure 1. Effect of the Real Exchange Rate under a Fixed Exchange Rate Regime.

The vertical lines of the above graph indicate the $95 \%$ confidence intervals of the probabilities of the sustainability of the current account deficit at different levels of the real exchange rate. The red intervals refer to the fixed exchange rate regime and those in blue the non-fixed exchange rate regime. The red curve describes the evolution of the effect of the real exchange rate under a fixed exchange rate regime, while the blue curve shows this evolution under a non-fixed exchange rate regime. When zero $(0)$ is not part of the red confidence interval, the real exchange rate has a significant effect on the sustainability of the current account deficit under a fixed exchange rate regime.

The graph shows that the red confidence intervals exclude the value zero (0) only from the real exchange rate corresponding to 700 . From this level, the real exchange rate has a significantly positive effect on the sustainability of the current account deficit in SSA countries using a fixed exchange rate regime. This result can be explained by the fact that the fixed exchange rate regime improves the competitiveness of economies by ensuring better long-term 
economic visibility. It is supported by the results found for the case of Argentina [9].

The results imply that the shift to a fixed exchange rate regime is conducive to improving the sustainability of the current account deficit only with high real exchange rates. A likely explanation is that the nominal exchange rate is not determined by market forces, which makes the automatic and spontaneous correction of current account imbalances difficult.

Figure 2 below shows the results of the effect of the real exchange rate on the sustainability of the current account deficit under an intermediate exchange rate regime.

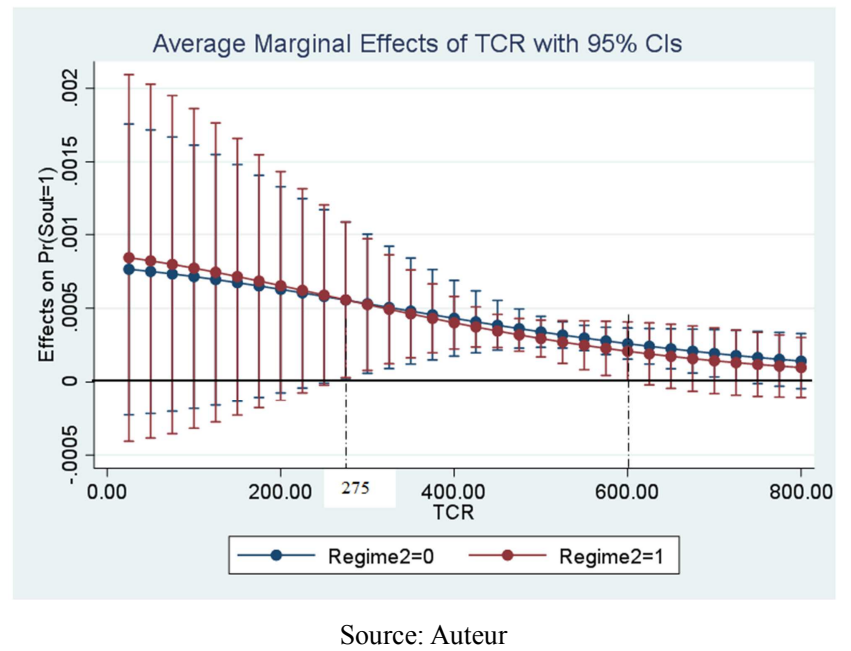

Figure 2. Effect of the Real Exchange Rate under an Intermediate Exchange Regime.

Under the intermediate exchange rate regime, the effect of the real exchange rate on the sustainability of the current account deficit of SSA countries is only significant when the real exchange rate is between 275 and 600 . Under these conditions, real exchange rate depreciation improves the sustainability of current account deficits of these countries. However, the red curve shows that the marginal effect decreases as the real exchange rate increases, and moving from a non-intermediate to an intermediate exchange rate regime decreases the marginal effect of the real exchange rate.

Compared to the fixed exchange rate regime, improving current account deficit sustainability in the intermediate exchange rate regime requires real exchange rate levels below 700. Figure 3 shows the results of the effect of the real exchange rate on the sustainability of the current account deficit for SSA countries under a floating exchange rate regime.

The graph shows that the marginal effect of the real rate of change in the case of the floating exchange rate regime is significantly positive and decreases as the real exchange increases, up to 250 . From this level, the confidence intervals for the floating exchange rate regime, that is to say those in red, no longer contain the value zero (0). The result obtained implies that for real exchange rate values less than or equal to 250 , the transition from a non-floating exchange rate regime to a floating exchange rate regime increases the probability of obtaining a sustainable deficit in SSA. This result is similar to that found for the case of the United States [13].

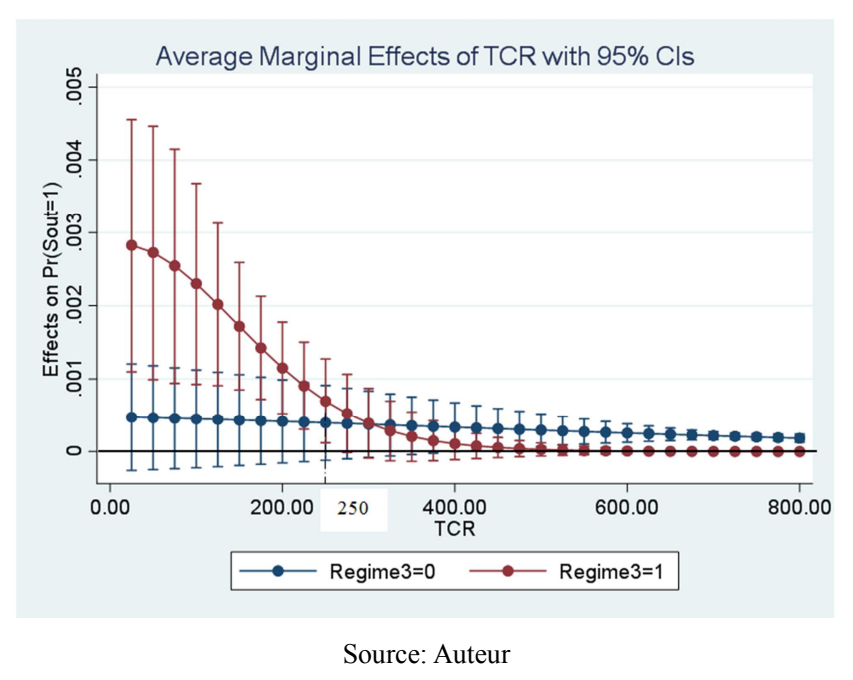

Figure 3. Effect of the Real Exchange Rate under a Floating Exchange Regime.

The particularity with the floating exchange rate regime is that it is possible to improve the sustainability of the current account deficit with lower real exchange rate levels, unlike the intermediate exchange rate regime and the fixed exchange rate regime.

The analysis of the results for SSA communities show that for ECOWAS countries using a fixed exchange rate regime, the real exchange rate has no effect on the sustainability of the current account deficit in the ECOWAS region (see figure 4). The intermediate exchange rate regime, on the other hand, allows the real exchange rate to positively and significantly influence the sustainability of the current deficit in ECOWAS for real exchange rate values less than or equal to 600 (see figure 5). Under a floating exchange rate regime, the marginal effect of the real exchange rate on the sustainability of the current account deficit is significantly positive when the real exchange rate is between 225 and 375 (see figure 6).

Concerning ECCAS, the effect of the real exchange rate is significantly positive on the sustainability of the deficit in the case of a fixed exchange rate regime, if the real exchange rate takes values between 70 and 460 (see figure 7). When the exchange rate is intermediate, the real exchange rate has a negative influence on the sustainability of the current account deficit in the ECCAS area, if the real exchange rate is between 70 and 280 (see figure 8). Regarding the floating exchange rate regime, the estimation of the marginal effect of the real exchange rate does not give results. This situation can be explained by the weak application of the floating exchange rate regime in the ECOWAS region. With reference to the Ilzetzki, Reinhart and Rogoff's database, no country in this area applied the floating exchange rate regime over the period 1980-2016. For the EAC, the estimate results indicate that the real exchange rate has no effect on the sustainability of the current account deficit, when the exchange rate regime is intermediate or floating (see figure 9 for the intermediate regime and figure 10 for the floating regime). Marginal effects of the real exchange rate do not appear for the fixed exchange rate regime, probably due to the low application of this exchange rate 
regime in the EAC space over the study period.

In the context of the SADC, the estimation of the empirical model reveals that in a fixed exchange rate regime, the real exchange rate has a positive and significant effect on the sustainability of the current account deficit, when it is greater than or equal to 505 (see figure 11). Likewise, when the real exchange rate is less than or equal to 235 , it positively influences the sustainability of the current account deficit of SADC countries in an intermediate exchange rate situation (see figure 12). The real exchange rate also favours the sustainability of the current account deficit in the case of the floating exchange rate regime for SADC countries, when it is between 190 and 385 (see figure 13).

\section{Conclusion}

This paper analysed the effect of the real exchange rate on the sustainability of the current account deficit of SSA countries over the period 1980-2016. After a theoretical and empirical review of the economic literature on the subject, a logit model of the sustainability of the current account deficit is specified.

The results obtained reveal that the real exchange rate has a positive and significant effect on the sustainability of the current account deficit in SSA countries. This effect varies depending on the types of exchange rate regime. The real exchange rate has a positive effect on the sustainability of the current deficit, when it is less than or equal to 250 for the floating exchange rate regime, between 275 and 600 for the intermediate exchange rate regime, and greater than 700 for the exchange rate regime fixed. It is therefore easier to improve the sustainability of the current account deficit through the real exchange rate in the floating exchange rate regime than in the intermediate and fixed exchange rate regime. Almost similar results are obtained when the estimate is made according to the different regional economic groupings in SSA.

The real exchange rate appears to be an appropriate instrument that the political authorities in SSA countries should use to restore the sustainability of their country's current account deficits. These authorities should take the exchange rate regime into account in the real exchange rate policy. They should use real exchange rates less than 250 for countries adopting a floating exchange rate regime, between 275 and 600 for the intermediate exchange rate regime and greater than 700 for the floating exchange rate regime.

\section{Appendix}

Table 5. Hausman Test.

\begin{tabular}{|c|c|c|c|c|c|}
\hline & SSA & ECOWAS & ECCAS & EAC & SADC \\
\hline Stat. Chi. 2 & $-84,67$ & 0,00 & $-3,32$ & 3,64 & $-14,79$ \\
\hline Prob. & - & 0,9909 & - & 0,7251 & - \\
\hline
\end{tabular}

Table 6. Heteroscedasticity Test.

\begin{tabular}{llllll}
\hline & SSA & ECOWAS & ECCAS & EAC & SADC \\
\hline Stat. F & 102,63 & 64,23 & 22,80 & 202,16 & 3,31 \\
Prob. & 0,0000 & 0,0000 & 0,0000 & 0,0000 & 0,0000 \\
\hline
\end{tabular}

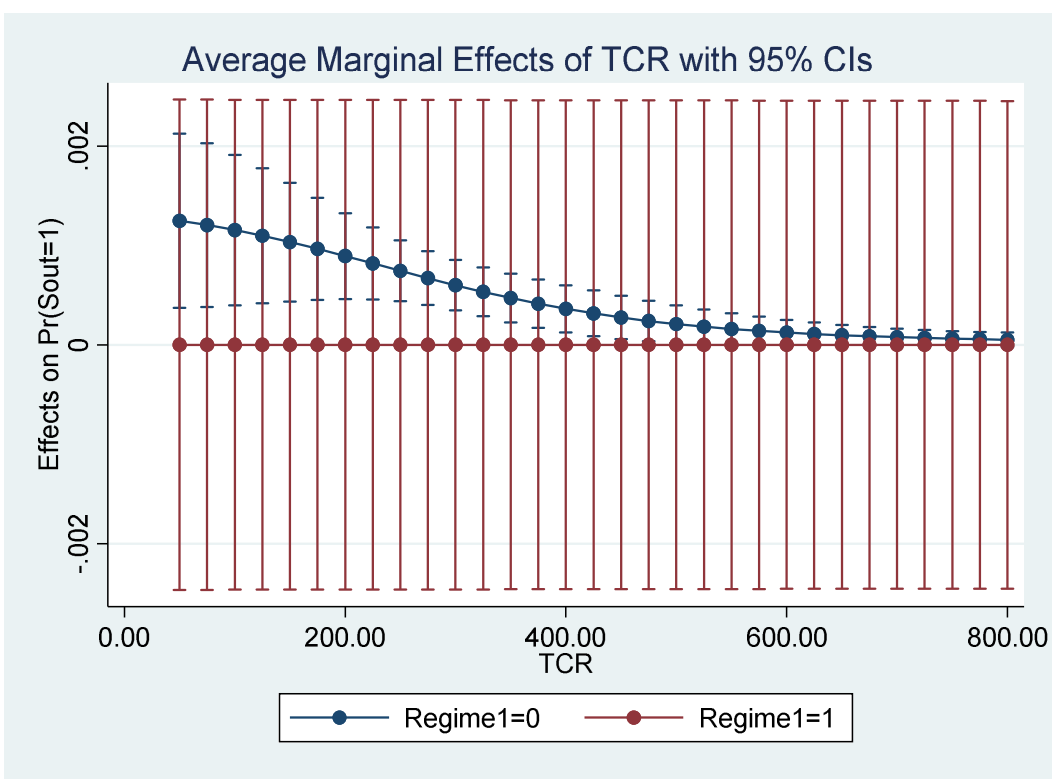

Figure 4. Effect of the Real Exchange Rate under a Fixed Regime for ECOWAS. 
Table 7. Prediction Test

\begin{tabular}{llllll}
\hline & SSA & ECOWAS & ECCAS & EAC & SADC \\
\hline Well-predicted sustainability cases & 732 & 77 & 115 & 56 & 121 \\
Number of sustainable cases & 909 & 94 & 146 & 77 & 152 \\
Well predicted unsustainability & 101 & 229 & 77 & 56 & 123 \\
Number of unsustainable cases & 133 & 287 & 100 & 69 & 157 \\
Total number of cases & 1042 & 381 & 246 & 146 & 309 \\
Prediction rate & 79,94 & 78,87 & 81,85 & 89,78 & 82,14 \\
\hline
\end{tabular}

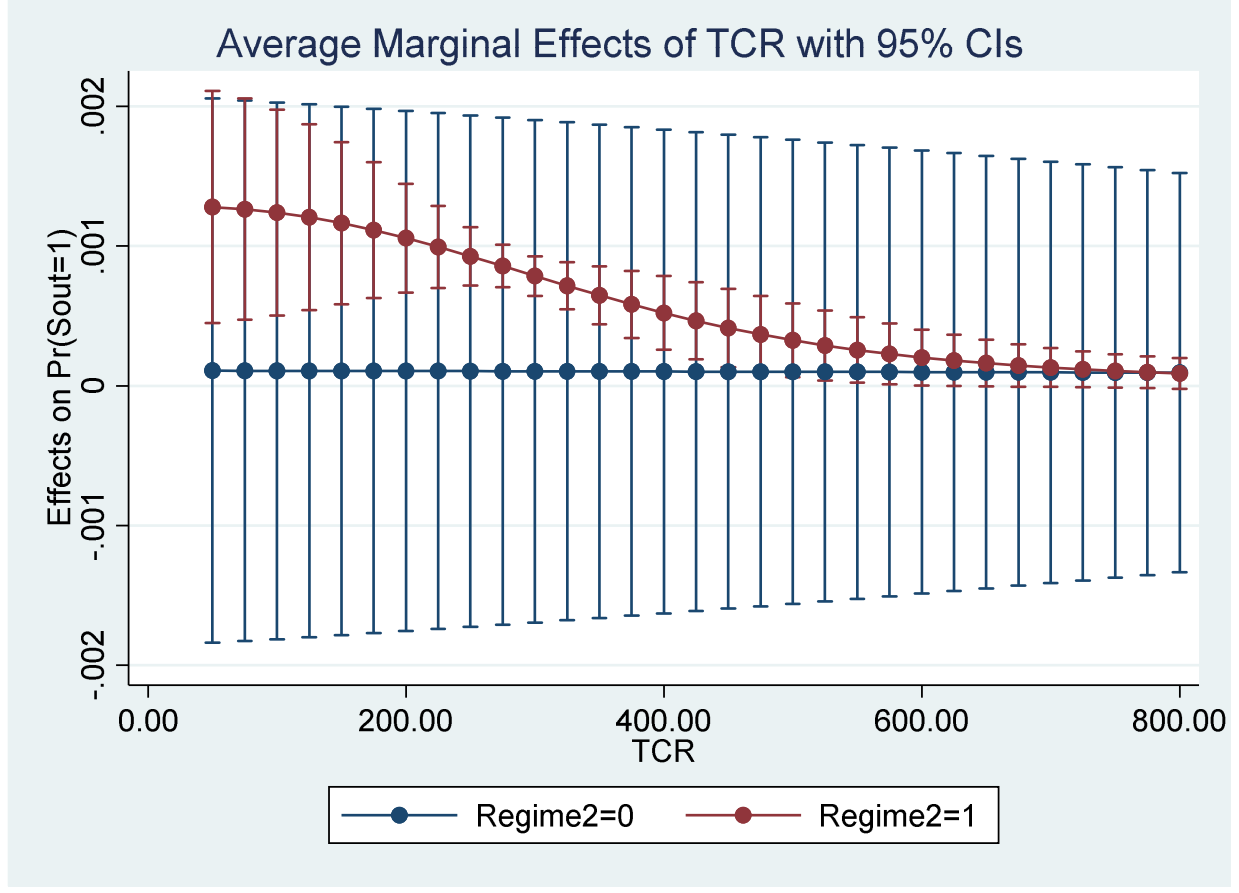

Figure 5. Effect of the Real Exchange Rate under an Intermediate Regime for ECOWAS.

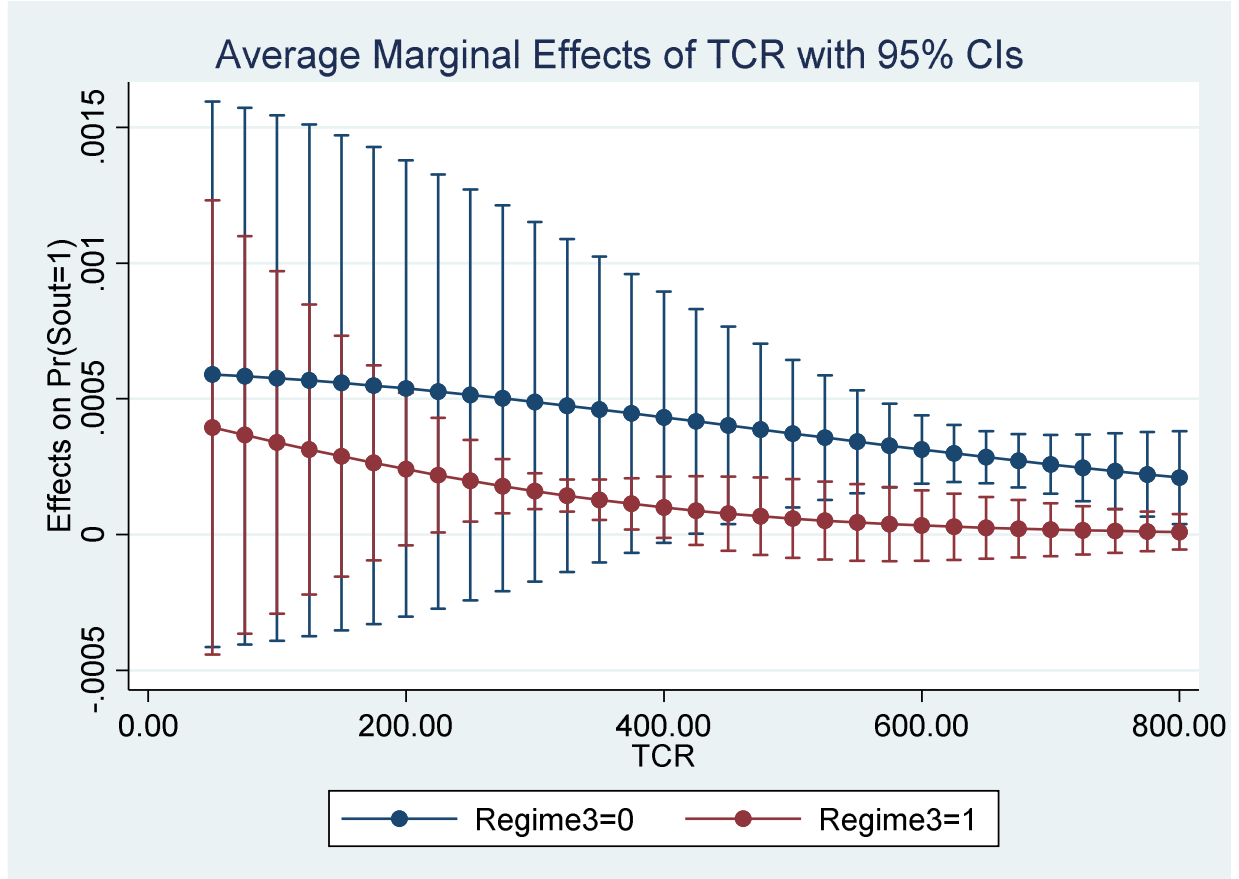

Figure 6. Effect of the Real Exchange Rate under a Floating Regime for ECOWAS. 


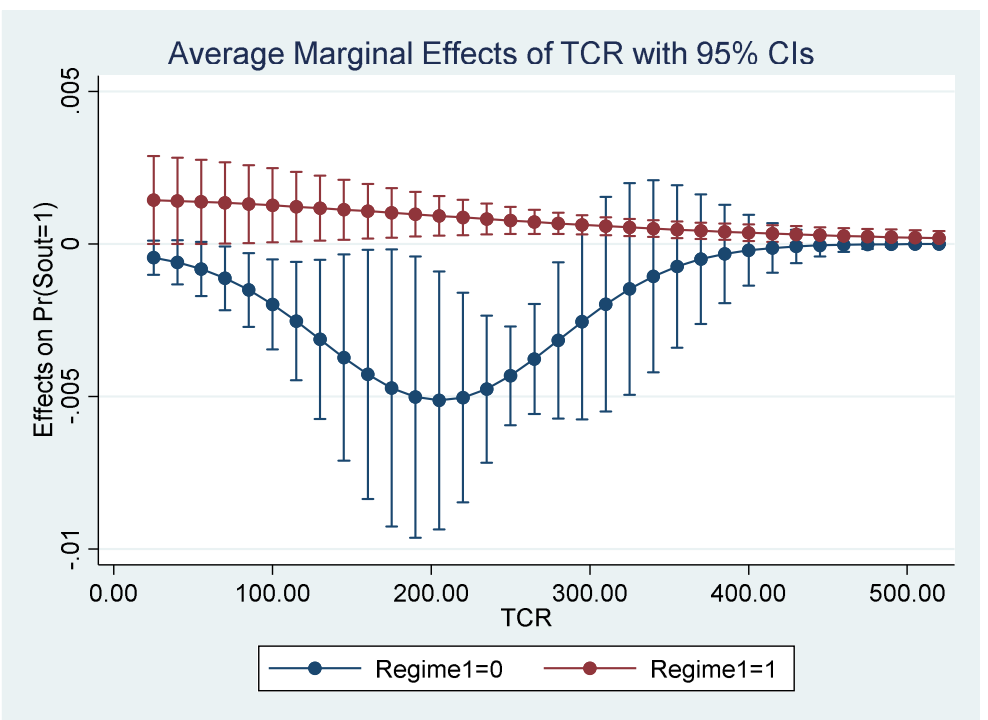

Figure 7. Effect of the Real Exchange Rate under a Fixed Regime for ECCAS.

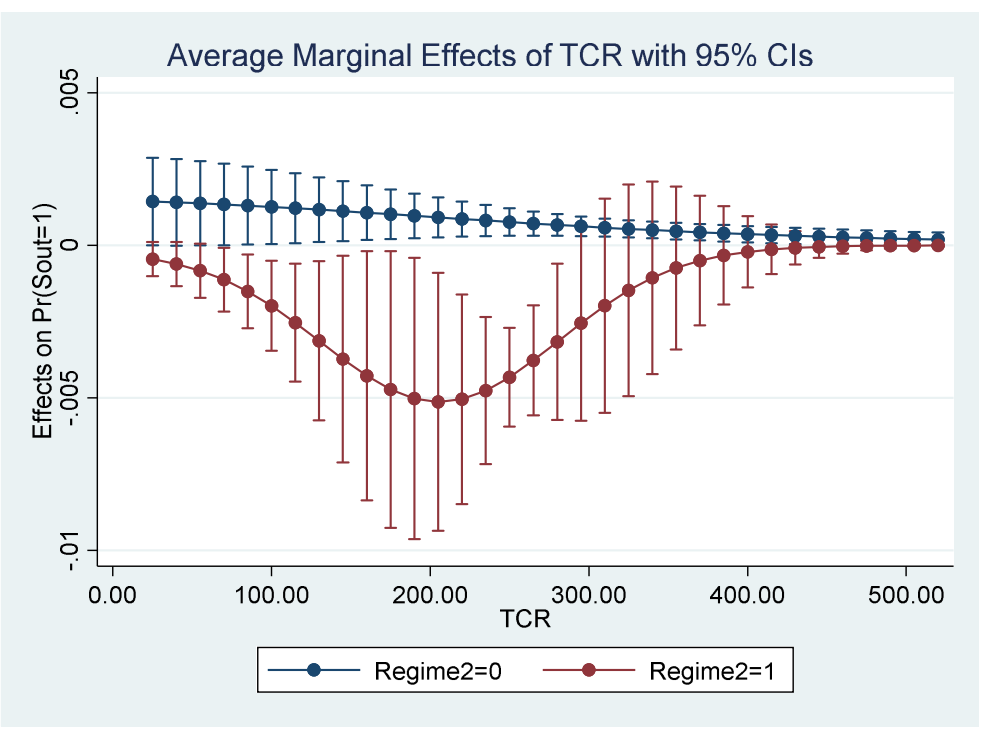

Figure 8. Effect of the Real Exchange Rate under an Intermediate Regime for ECCA.

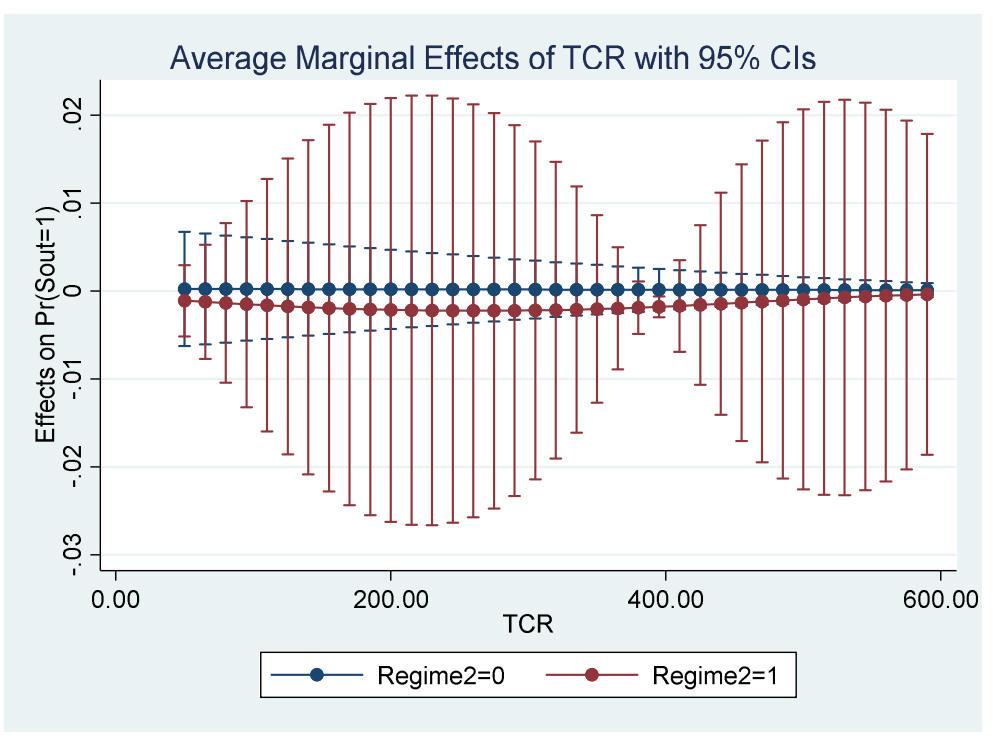

Figure 9. Effect of the Real Exchange Rate under an Intermediate Regime for EAC. 


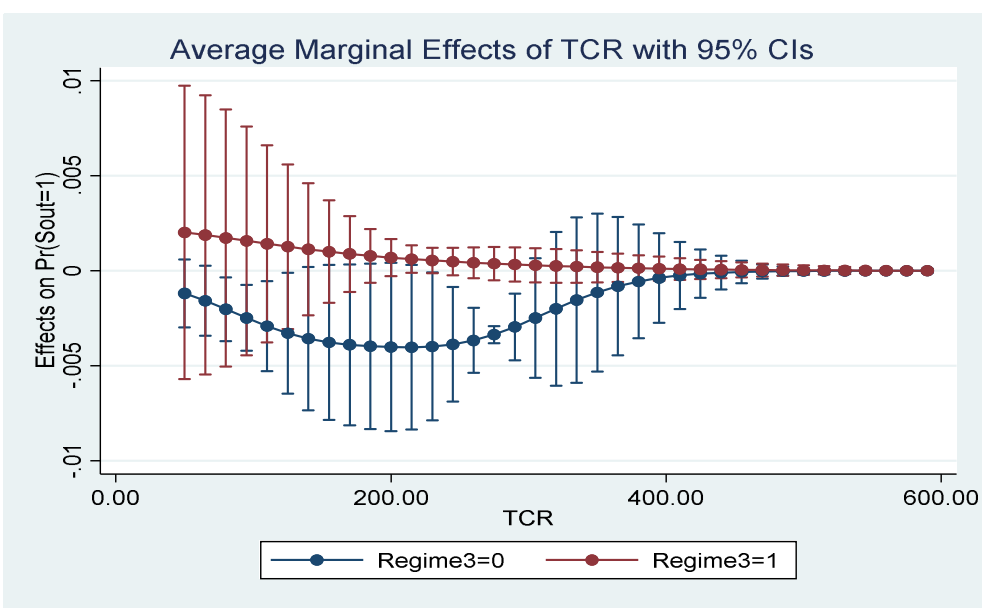

Figure 10. Effect of the Real Exchange Rate under a Floating Regime for EAC.

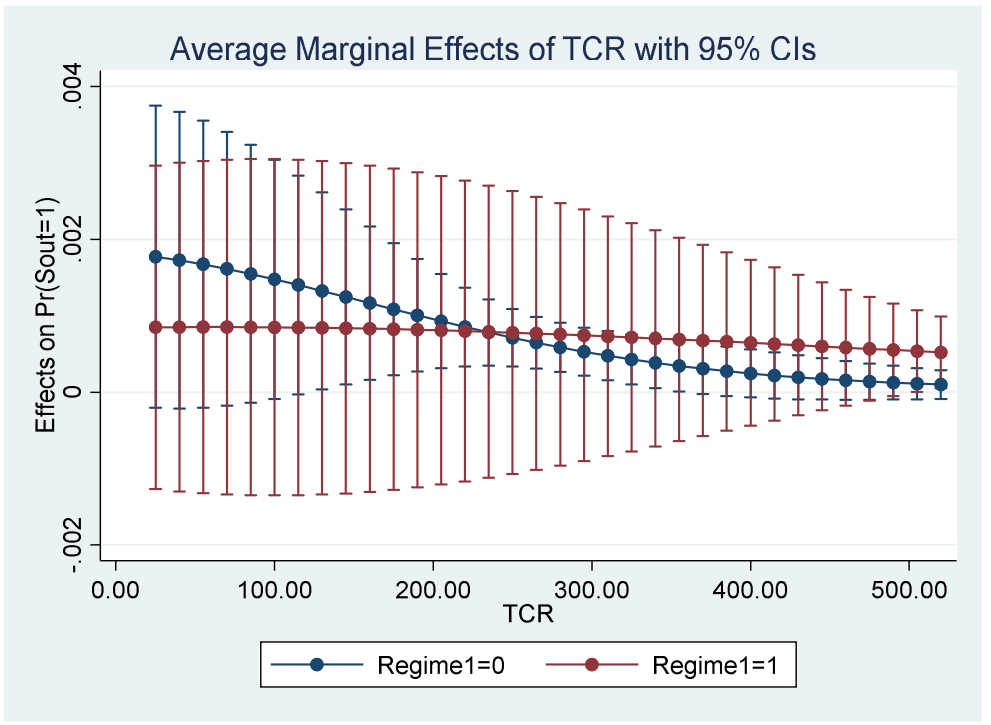

Figure 11. Effect of the Real Exchange Rate under a Fixed Regime for SADC.

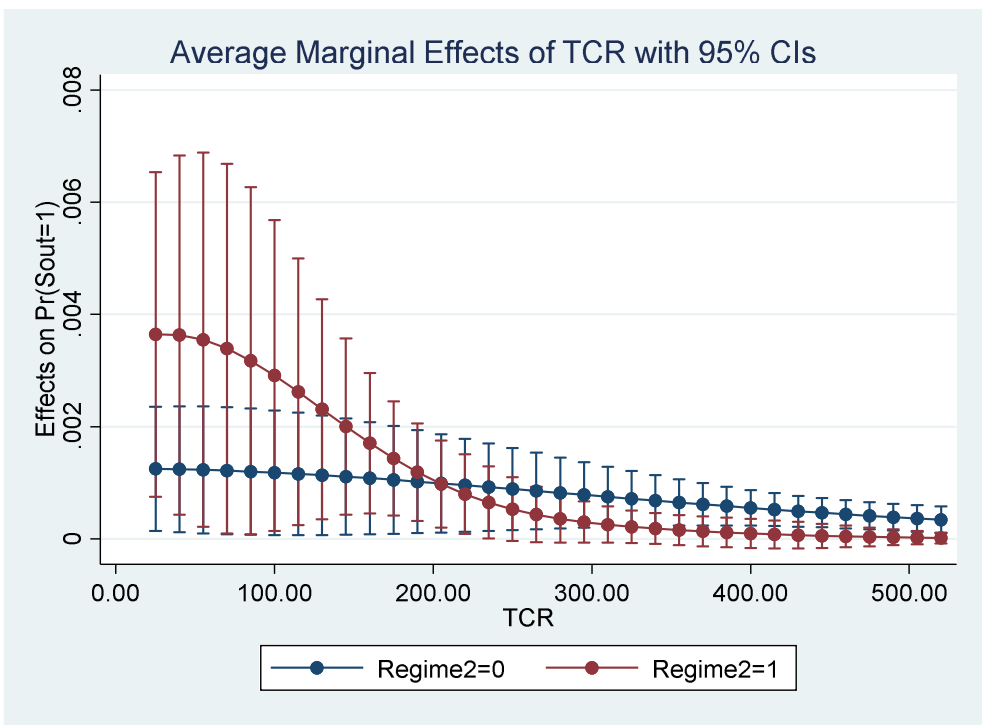

Figure 12. Effect of the Real Exchange Rate under an Intermediate Regime for SADC. 


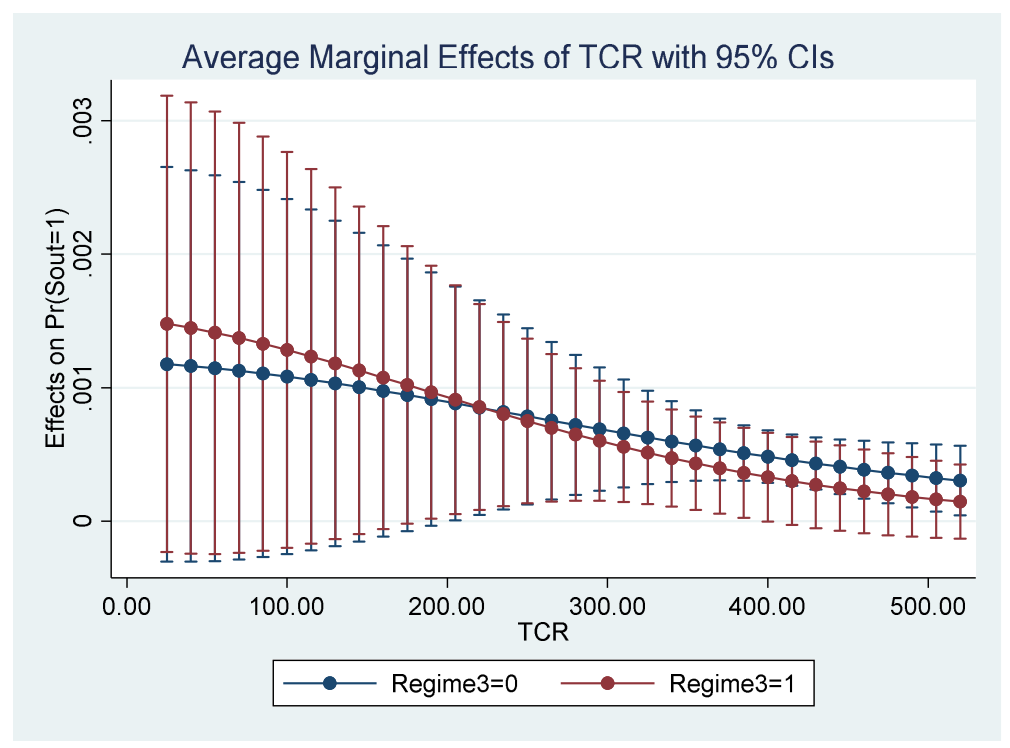

Figure 13. Effect of the Real Exchange Rate under a Floating Regime for SADC.

\section{References}

[1] Reinhart, G., Goldstein, M., \& Kaminsky, G. (2000). Early warning system: an assessment of vulnerability, MPRA Paper, no. 24579 .

[2] Milesi-Ferretti, G. M., \& Razin, A. (1996). Sustainability of Persistent Current Account Deficits, National Bureau of Economic Research Working Paper, no. 5467.

[3] Robinson, J. (1947). Essays in the Theory of Employment, Oxford: Basil Blackwell.

[4] Alexander, S. S. (1952). Effects of Devaluation on the Trade Balance, International Monetary Fund Staff Papers, vol. 2, no. 2, pp. 263-278.

[5] Polak, J. (1957). Monetary Analysis of Income Formation and Payments Problems, Staff Papers, International Monetary Fund.

[6] Krugman, P. (1991). Has the Adjustment Process Worked?, Washington: Institute for International Economics.

[7] Guillaumont, P., \& Guillaumont Jeanneney, S. (1992). Les conséquences sociales de l'ajustement en Afrique selon la politique de change, Politique africaine, no. 45, pp. 101-122.

[8] Obstfeld, M. (2002). Exchange Rates and Adjustment: Perspectives from the New Open-Economy Macroeconomics," Monetary and Economic Studies, vol. 20, no. 1 , pp. 23-46.

[9] Gomez, D. M., \& Alvarez-Ude, G. F. (2007). Exchange rate policy and trade balance: A cointegration analysis of the argentine experience since 1962, Working Paper of University of Oviedo.

[10] Kouam, S. F. C., Ekomie, A. A., \& Bahouayila, C. (2010). Effet du taux réel sur la balance commerciale: Cas du Gabon, Document de travail de l'Institut Sous-régional de Statistiques et d'Economie Appliquée (ISSEA), pp. 1-46.

[11] Tunaer Vural, B. M. (2016). Effect of Real Exchange Rate on
Trade Balance: Commodity Level Evidence from Turkish Bilateral Trade Data, Procedia Economics and Finance, vol. 499-507, pp. 499-507.

[12] Ibrahim, T. R., Akinbobola, T. O., \& Ikotun, J. A. (2017). Exchange Rate Reform Policies and Trade Balances in Nigeria, European Journal of Business and Management, vol. 9 , no. 7 , pp. 33-45.

[13] Bahmani-Oskooee, M., \& Harvey, H. (2018). The US trade balance with partners from developing World: An asymmetry analysis of the J-curve effect, Journal of Economic Development, vol. 43, no. 2, pp. 29-43.

[14] Friedman, M. (1953). Essays in Positive Economics, Chicago: University of Chicago Press.

[15] Ondo, O. A. (1992). Taux de change du franc CFA et construction européenne, Mondes en développement, vol. 20, no. $77 / 78$, pp. $59-74$.

[16] Masera, R. (1974). The J-Curve: UK Experience after the 1967 Devaluation, Metroeconomica, vol. 26, pp. 40-62.

[17] Mundell, R. A. (1960). The monetary dynamics of international adjustment under fixed and flaoting exchange rate, Quaterly Journal of Economics, vol. 74, pp. 227-257.

[18] Mundell, R. A. (1961). A theory of optimum currency areas, American Economic Review, vol. 51, no. 3, pp. 657-665.

[19] McKinnon, R. (1963). Optimum currency areas, American Economic Review, vol. 53, pp. 717-724.

[20] Kenen, P. (1969). The Theory of Optimum Currency Areas: An Eclectic View in Mundell and Swoboda (eds.) Monetary Problems in the International Economy, Chicago: University of Chicago Press.

[21] Duasa, J. (2007). Determinants of Malaysian Trade Balance: An ARDL Bound Testing Approach, Global Economic Review, vol. 36, no. 1, pp. 89-102.

[22] Herrman, S. (2009). Do we really know that flexible exchange rates facilitate current account adjustment ? Some new empirical evidence for CEE countries, Deutsche Bundesbank Discussion Paper, no. 22. 
[23] Mazier, J., \& Aliti, G. T. T. (2010). Déséquilibres mondiaux, taux de change et ajustements macroéconomiques Un modèle «stock flux cohérent» à trois pays, Revue économique, vol. 61, no. 3, pp. 463-475.

[24] Ghosh, A. R., Qureshi, M. S., \& Tsangarides, C. G. (2014). Friedman Redux: External Adjustment and Exchange Rate Flexibility, International Monetary Fund Working Paper, no. WP/14/146.

[25] Berka, M., Devereux, M. B., \& Engel, C. (2012). Real Exchange Rate Adjustment in and out of the Eurozone, American Economic Review: Papers \& Proceedings, vol. 102, no. 3, pp. 179-185.

[26] Clower, E., \& Ito, H. (2012). The Persistence of Current Account Balances and its Determinants: The Implications for Global Rebalancing, Asian Development Bank Institute Working Paper, no. 400.

[27] Chinn, M. D., \& Wei, S. J. (2013). A faith-based initiative meets the evidence: does a flexible exchange rate regime really facilitate current account adjustement ?, Review of Economics and Statistics, vol. 95, no. 1, p. 168-184.

[28] Cavdar, S. C., \& Aydin, A. D. (2015). A Different Perspective for Current Account Deficit Issue on Some OECD Member Countries: A Binary Panel Logit Approach, World Economy, vol. 6 , no. 3, pp. 14-22.

[29] Summers, L. H. (1996). Commentary, Inter-American Development Bank, Washington DC.
[30] Mann, C. (2002). Perspectives on the U. S. current account deficit and substainability, Journal of Economic Perspectives, vol. 16 , no. 3 , pp. 131-152.

[31] BCEAO (2013). Analyse de la viabilité et des déterminants du déficit courant des pays de l'Union Economique et Monétaire Ouest Africaine (UEMOA), Document de travail, Dakar.

[32] Ai, C., \& Norton, E. C. (2003). Interaction terms in logit and probit models, Economics Letters, vol. 8, pp. 123-129.

[33] Norton, E. C., Wang, H., \& Ai, C. (2004). Computing interaction effects and standard errors in logit and probit models, The Stata Journal, vol. 4, no. 2, pp. 154-167.

[34] Ilzetzki, E., Reinhart, C. M., \& Rogoff, K. S. (2017). Exchange arrangements entering the 21st century: Which anchor will old ?, Working paper of National Bureau of Economic Research, no. 23134.

[35] Hausman, J. A. (1978). Specification tests in econometrics, Econometrica, vol. 46, pp. 1251-1271.

[36] Cameron, A. C., \& Trivedi, P. K. (2009). Microeconometrics Using Stata, Texas: A Stata Press Publication.

[37] White, H. (1980). A Heteroskedasticity-Consistent Covariance Matrix Estimator and a Direct Test for Heteroskedasticity, Econometrica, vol. 48, no. 4, pp. 817-838. 